\title{
Penetration and systemic absorption of gentamicin after subconjunctival injection
}

\author{
M. B. R. MATHALONE AND A. HARDEN \\ Royal Eye Hospital, London, S.E. I
}

Gentamicin is a highly stable water-soluble antibiotic produced by Micromonospora purpurea. It was first isolated in 1963 and became commercially available in 1969 (Cox, 1970). It is available as an intramuscular injection and can be given in the form of eye drops or as a subconjunctival injection.

Gentamicin is of special interest to ophthalmologists because of its wide range of activity against Gram-positive and Gram-negative bacteria, with marked activity against Pseudomonas, Proteus, and E. coli (Jackson, 1967; Cox, 1970).

The purpose of this study was to determine the intraocular absorption of gentamicin after subconjunctival injection before cataract extraction, and to determine corresponding serum levels in relation to known therapeutic and toxic levels.

Systemic administration has resulted rarely in ototoxic effects on the vestibular apparatus similar to those caused by antibiotics structurally related to gentamicin-neomycin, streptomycin, and kanamycin (Jackson, I967; Cox, 1970). These cases usually resulted from the administration of large doses to patients with impaired renal function, as the drug is almost all eliminated via the kidneys. Gentamicin has a similar structure to the kanamycin, neomycin, and streptomycin group in that all contain two amino-sugar molecules. Gentamicin itself is a complex of three antibiotics, $\mathbf{C}_{\mathbf{1}}, \mathbf{C}_{\mathbf{2}}, \mathbf{G}_{\mathbf{1}}$, which differ in structure only by one or two $\mathrm{CH}_{3}$ groups, but the activity and toxicity of these individual components are virtually the same as those of the complex.

Cox (1970) showed, using Io and $2 \mu \mathrm{g}$. discs, that the vast majority of organisms will be inhibited by $5^{-6 \mu \mathrm{g}} / \mathrm{ml}$. or less of the drug. Cross-sensitization with kanamycin and neomycin and spontaneous resistance is very rare and gentamicin has been reported to act synergistically with carbenicillin against Pseudomonas.

\section{Method}

2 I patients had $40 \mathrm{mg}$. gentamicin injected subconjunctivally 30 minutes before surgery, three had $20 \mathrm{mg}$., and three $80 \mathrm{mg}$.

The anterior chamber was opened by a broad needle and aqueous was drawn into a dry 2-ml. syringe under microscopic control. The anterior chamber was reconstituted with saline and the cataract extraction continued $a b$ externo in the normal way.

Blood samples were taken preoperatively, during surgery, and $2 \mathrm{hrs}$ postoperatively. The samples were stored at $-4^{\circ} \mathrm{C}$. and assay was arranged by Roussel Laboratories. 
The Tables show the aqueous and serum levels of gentamicin obtained after subconjunctival injections of 40,20 , and $80 \mathrm{mg}$. gentamicin sulphate.

These results show that effective levels of gentamicin in the primary aqueous are consistently achieved with a subconjunctival injection of $40 \mathrm{mg}$. gentamicin sulphate and that with this dose the related serum levels are very low and always at non-toxic levels.

Table I $40 \mathrm{mg}$. injected in 2 I cases

\begin{tabular}{|c|c|c|c|c|}
\hline \multirow{2}{*}{$\begin{array}{l}\text { Case } \\
\text { no. }\end{array}$} & \multirow{2}{*}{$\begin{array}{l}\text { Aqueous level } \\
(\mu g . / m l .)\end{array}$} & \multicolumn{3}{|c|}{ Serum levels $(\mu g . / m l)}$. \\
\hline & & $\begin{array}{l}\text { Pre- } \\
\text { operative }\end{array}$ & $\begin{array}{l}\text { During } \\
\text { operation }\end{array}$ & $\begin{array}{l}2 \text { hrs after } \\
\text { operation }\end{array}$ \\
\hline $\mathbf{I}$ & $8 \cdot 4$ & \multicolumn{3}{|c|}{ No detectable level } \\
\hline 2 & $10 \cdot 6$ & Nil & $0 \cdot 17$ & $0 \cdot 14$ \\
\hline 3 & Insufficient obtained & Nil & $0 \cdot 15$ & $0 \cdot 10$ \\
\hline 4 & $3 \cdot 7$ & Nil & $0 \cdot 37$ & $0 \cdot 16$ \\
\hline $5^{*}$ & 2.0 & Nil & $0 \cdot 12$ & $0 \cdot 10$ \\
\hline 6 & $4 \cdot j$ & Nil & $0 \cdot 39$ & $0 \cdot 10$ \\
\hline 7 & $5 \cdot 6$ & Nil & 0.17 & $0 \cdot 10$ \\
\hline 8 & $14 \cdot 4$ & Nil & $0 \cdot 09$ & $0 \cdot 08$ \\
\hline 9 & $8 \cdot 7$ & Nil & $0 \cdot 09$ & trace \\
\hline IO & $18 \cdot 9$ & Nil & $0 \cdot 45$ & trace \\
\hline I I & $2 \cdot 5$ & Nil & $0 \cdot 43$ & not taken \\
\hline 12 & $4 \cdot 4$ & Nil & $0 \cdot 7$ & not taken \\
\hline I3 & Insufficient obtained & Nil & 0.625 & not taken \\
\hline 14 & $10 \cdot 1$ & Nil & 0.603 & $0 \cdot 45$ \\
\hline I 5 & $13 \cdot 8$ & Nil & $0 \cdot 26$ & $0 \cdot 23$ \\
\hline I 6 & $18 \cdot 0$ & Nil & $0 \cdot 32$ & $0 \cdot 13$ \\
\hline 17 & $17 \cdot 0$ & Nil & 0.52 & 0.68 \\
\hline 18 & $7 \cdot 3$ & Nil & $0 \cdot 09$ & $0 \cdot 07$ \\
\hline 19 & $2 \cdot 25$ & Nil & $0 \cdot 37$ & $0 \cdot 24$ \\
\hline 20 & $9 \cdot 5$ & Nil & $0 \cdot 71$ & $0 \cdot 18$ \\
\hline 21 & I $6 \cdot 0$ & Nil & No detec & e level \\
\hline
\end{tabular}

*Vitreous loss during extraction; $9 \cdot 3 \mu \mathrm{g} . / \mathrm{ml}$. from specimen of vitreous

Table II $20 \mathrm{mg}$. injected in three cases

\begin{tabular}{|c|c|c|c|c|}
\hline \multirow{2}{*}{$\begin{array}{l}\text { Case } \\
\text { no. }\end{array}$} & \multirow{2}{*}{$\begin{array}{l}\text { Aqueous level } \\
(\mu g . / m l .)\end{array}$} & \multicolumn{3}{|c|}{ Serum levels $(\mu \mathrm{g} . / \mathrm{ml})}$. \\
\hline & & $\begin{array}{l}\text { Pre- } \\
\text { operative }\end{array}$ & $\begin{array}{l}\text { During } \\
\text { operation }\end{array}$ & $\begin{array}{l}2 \text { hrs after } \\
\text { operation }\end{array}$ \\
\hline I & $9 \cdot 9$ & Nil & $0 \cdot I_{1}$ & $0 \cdot 13$ \\
\hline 2 & $6 \cdot 5$ & Nil & Nil & Nil \\
\hline 3 & $3 \cdot 8$ & Nil & Nil & Nil \\
\hline
\end{tabular}


Table III 8o mg. injected in three cases

\begin{tabular}{|c|c|c|c|c|}
\hline \multirow{2}{*}{$\begin{array}{l}\text { Case } \\
\text { no. }\end{array}$} & \multirow{2}{*}{$\begin{array}{l}\text { Aqueous level } \\
(\mu g . / m l .)\end{array}$} & \multicolumn{3}{|c|}{ Serum levels $(\mu g . / m l)}$. \\
\hline & & $\begin{array}{l}\text { Pre- } \\
\text { operative }\end{array}$ & $\begin{array}{l}\text { During } \\
\text { operation }\end{array}$ & $\begin{array}{l}2 \text { hrs after } \\
\text { operation }\end{array}$ \\
\hline I & I 4.6 & Nil & $I \cdot 2$ & 0.82 \\
\hline 2 & I 7.6 & Nil & $0 \cdot 75$ & $0 \cdot 32$ \\
\hline 3 & I 4.9 & Nil & 0.9 & $0 \cdot 3$ \\
\hline
\end{tabular}

\section{Discussion}

These results may be compared with experimental evidence in rabbits, in which levels satisfactory against Gram-negative organisms have been found after subconjunctival injection, although not after intramuscular injection except in the secondary aqueous (Furgiuele, 1967; Litwack, Pettit, and Lamar Johnson, 1969). It is interesting to see the expected differences in dose-related levels using 80 and $20 \mathrm{mg}$. injections and also using ro mg. as reported by Furgiuele (1970).

A comparison can be made with the results reported by Bron and his colleagues using Soframycin, when appreciable serum levels were reported after subconjunctival injection (Bron, Richards, Knight-Jones, Easty, and Ainslie, 1970). These were of a similar order to those reported by Massénat-Déroche (1954) after the intramuscular injection of $250 \mathrm{mg}$. framycetin sulphate in adults. These authors discuss the reasons for the difference between the serum levels after administration of this drug by a number of other routes. They state that the literature does not record the blood levels of neomycin which may be regarded as toxic, nor how long a minimum serum level must act to produce toxic effects in man. They point out that, after over ro years of clinical use, no report of systemic toxic effects has been made, but this must remain a potential danger, especially in patients with renal disease and in children.

Gentamicin, with its wide spectrum of antibacterial activity and low incidence of undesirable systemic side-effects, promises to be of increasing value in the treatment of established ocular infection and local sepsis following surgery. Furgiuele (1970) reports on a similar study to this using Io mg. gentamicin subconjunctivally in fifteen patients about to have cataract surgery. He found satisfactory aqueous levels after the injection of Io mg. gentamicin subconjunctivally, but in four cases the serum levels were much higher than in our series. It is difficult to explain why this is so as the blood levels in our cases were fairly consistently low and in only one case (No. 17) was it over $0.6 \mu \mathrm{g} . / \mathrm{ml}$. after 2 hours.

From our present knowledge there appears to be no contraindication to the use of gentamicin subconjunctivally in patients with ocular infections caused by one of the wide range of organisms destroyed by the drug, but as in its use for systemic infections, care should be taken in patients with impaired renal function.

\section{Conclusions}

This study suggests that an effective level of gentamicin can be obtained in the aqueous humour by a subconjunctival injection of $40 \mathrm{mg}$. gentamicin sulphate base. Howeverwhen secondary aqueous is present a much lower dose of gentamicin will result in satis, factory aqueous levels. The drug may be used prophylactically in intraocular surgery or therapeutically in intraocular infections as it has a wide spectrum of activity which 
includes most of the organisms usually isolated in cases of bacterial ocular infection. In no case was there any adverse reaction to the drug locally or systemically.

We wish to acknowledge the help given by Roussel Laboratories and especially by Dr. A. Atkinson and Dr. L. Hughes.

\section{References}

BRON, A. J., Richards, A. B., KNIGHT-JONes, D., EASTy, D. L., and AINSLIE, D. (I970) Brit. J. Ophthal., 54, 6 I 5

cox, c. E. (1970) Med. Clin. N. Amer., 55, i 305

FUrgiuele, F. P. (1967) Amer. F. Ophthal., 64, 421

(1970) Ibid., 69, $48 \mathrm{I}$

JACKson, G. G. (1967) Practitioner, 198, 855

litwack, K. D., PEtTit, T., and lamar Johnson, B., JR. (1969) Arch. Ophthal. (Chicago), 82, 687

massénat-déroche, B. (1954) Thèse, Paris, No. 346, p. 213 